\title{
Group Guidance Based On Javanese Character with Merchant Morals to Improve Student Resilience
}

\author{
Denok Setiawati ${ }^{1,2, *}$ Bambang Budi Wiyono ${ }^{1}$, Nur Hidayah ${ }^{1}$, Adi Atmoko ${ }^{1}$, Arbin Janu Setiyowati ${ }^{1}$ \\ ${ }^{1}$ State University of Malang \\ ${ }^{2}$ State University of Surabaya
}

\begin{abstract}
The purpose of this study was to test the effectiveness of group guidance based on Javanese character to improve student resilience. This type of research was a quantitative research with one group Pre-test-Post-test design. The data collection technique was in the form of a resilience scale. The research subjects were 7 students who were taken randomly. The data analysis technique used non-parametric statistics with the Wilcoxon technique. The result of the Wilcoxon test showed the value of $\mathrm{Z}=-2,371$ with asymp sid (2-tailed) 0.018 . It's means that there was a significant difference of student resilience level between Pre-test and Post-test. So this means that there was significant difference between before and after the application of group guidance. For further research can be done by develop a group guidance guide or the other experimental research design.
\end{abstract}

Keywords: Student Resilience, Group Guidance, Javanese Character

\section{INTRODUCTION}

Resilience for students is very important. As defined, resilience is the ability to survive, adapt to something that is pressing, be able to overcome and go through, and be able to recover from adversity (Reivich and Shatte, 2002; Eşkisu, 2021). This means that someone who has good resilience will be able to develop optimally and be able to solve life problems well so that he has mental health, psychological well-being and is productive (Shatte, 2017; Wexler L, et al; 2014; Amir, Rezaei and Tazesh, 2016 ; et.all, 2014;2015;2017).

By nature, individuals have different levels of resilience. However, if it is not accompanied, problems will arise, both high and low resilience. As revealed by Singgih (2020), that the failure of the large-scale social restriction policy (PSBB) in suppressing the Covid-19 rate in Surabaya in 2020 is due to the high level of resilience character. On the other hand, someone who has low resilience if left alone will also experience distress. psychological impact on physical and mental health and even death, (Azzahra, 2017). For this reason, so that student resilience can develop well, it needs to be accompanied through certain strategies (Farquhar, Kamei, Vidyarthi, 2018).

The assistance in question is through guidance activities based on Javannese character. One of the named character "Budi Saudagar" or Merchant's Morals. Budi Saudagar is used to describe a person who has a calculating, frugal, careful character, in his steps he always considers everything carefully the pros and cons, and the risks (Jumantara 2014; Sumodiningrat and Wulandari, 2014: 63). The characters above are in accordance with the independence standards of students achieved through guidance and counseling services, namely intellectual maturity (Depdikbud, 2007). A student can achieve success in his life is also determined by his character, (Rosita, 2018).
Several studies on the Javanese character of merchant's morals who are included in the teachings of chess of mind in Serat Sana Sunu have found that this teaching is still relevant to be applied today (Daryanto, 2017). Another research conducted by Santosa (2016), the values contained in Serat Sana Sunu include the teachings on merchant's morals that can be used as the basis for Indonesian national education practices (Santosa, 2016). The type of guidance applied is group guidance based on the character of merchants. Group guidance is useful for supporting career development, social development and increasing self-awareness with four stages, namely the initial or formation stage, the transition stage, the activity stage and the termination stage, (Gibson and Mitchell 2011; Prayitno, 2004). The research question of this study is: is there any difference in the level of student resilience between before and after the implementation of group guidance based on Javanese character with merchant morals? And the hypothesis of this research is: there is a difference in the level of student resilience between

Corresponding Author e-mail: denok.setiawati.2001119@students. um.ac.id

\section{https://orcid.org/0000-0002-8632-4633}

How to cite this article: Setiawati D, Wiyono BB, Hidayah N, Atmoko A, Setiyowati AJ, (2021). Group Guidance Based On Javanese Character with Merchant Morals to Improve Student Resilience. Pegem Journal of Education and Instruction, Vol. 11, No. 4, 2021, 78-81

Source of support: Nil

Conflict of interest: None.

DOI: $10.47750 /$ pegegog. 11.04 .08

Received: 05.05.2021

Accepted: 01.07.2021 Publication: 01.10.2021 
before and after implementation of group guidance based on Javanese character with merchant morals.

\section{Method}

\section{Research Design}

This research is a quasi-experimental quantitative research with one group Pre-test-Post-test design. Before treatment, measurements were made using a resilience scale to measure the level of resilience. Next, treatment is given in the form of group guidance based on Javanese character with "Budi Saudagar" or merchant morals and then measured again with the same measuring instrument to see the difference in students' resilience levels.

\section{Population and Sample/ Study Group/Participants}

The number of research subjects was 7 students taken randomly. The research subjects came from students who lived in Surabaya and were of Javanese ethnicity, this was

Table 1 The Result Of Problem Items between Before and After Treatment

\begin{tabular}{lllll}
\hline $\begin{array}{l}\text { Number of } \\
\text { Item }\end{array}$ & Pre-test & Category & Pre-test & Category \\
\hline 1 & 18 & Moderate & 22 & Moderate \\
2 & 17 & Moderate & 22 & Moderate \\
3 & 16 & Problematic & 22 & Moderate \\
4 & 18 & Moderate & 22 & Moderate \\
5 & 20 & Moderate & 23 & Moderate \\
6 & 21 & Moderate & 25 & Moderate \\
7 & 19 & Moderate & 23 & Moderate \\
8 & 19 & Moderate & 22 & Moderate \\
9 & 24 & Moderate & 24 & Moderate \\
10 & 22 & Moderate & 25 & Moderate \\
11 & 19 & Moderate & 22 & Moderate \\
12 & 18 & Moderate & 22 & Moderate \\
13 & 17 & Moderate & 22 & Moderate \\
14 & 20 & Moderate & 23 & Moderate \\
\hline
\end{tabular}

done because the treatment was in the form of character-based group guidance originating from the Javanese community. Meanwhile, the level of student resilience is not an important consideration but is still measured. The level of resilience is divided into 3 categories, namely 14-28 for the low category, 29-37 for the medium category and 38-56 for the high category.

\section{Data Collection Tools}

The data collection method used is a resilience scale with seven indicators including emotion regulation, impulse control, optimism, causal analysis, empathy, self-efficacy and reaching out. The existing indicators were then developed into 14 statement items with four possible answers, namely never, rarely, often and always which have been through validity and reliability tests. The results of Cronbach's Alpha reliability statistics are 0.844 , meaning that it has met the reliable criteria and the results of the Anova test with a grand mean of 2.9571 which means that all items are declared valid.

\section{Data Collection}

The resilience scale is given to students prior to conducting guidance services based on the Javanese character with merchant morals and determine the category or level of student resilience. This scale is given by utilizing googleform. Data collection was carried out by circulating the resilience scale first to 7 students, after knowing the level of resilience, then treatment was given and then the resilience was measured again. The grouping of items is classified into 3, namely 7-16 problematic groups, 17-26 moderate groups, and 27-28 no problems.

\section{Data Analysis}

Data analysis technique used non-parametric statistic Wilcoxon technique. This technique is used to determine the difference in the mean before and after treatment and it will be known which subjects are in the positive or negative rank. After that, the $\mathrm{Z}$ value will be calculated with an alpha of 0.05 if the data $1 \leq 2$ is obtained, it can be concluded that there is a difference in the level of resilience between before and after treatment.

Table 2 Pre-test-Post-test Result

\begin{tabular}{lllllll}
\hline Number & Initial & Pre-test & Level & Post-test & Level & Different \\
\hline 1 & Student 1 & 39 & High & 43 & High & 4 \\
2 & Student 2 & 38 & High & 43 & High & 5 \\
3 & Student 3 & 29 & Medium & 43 & High & 14 \\
4 & Student 4 & 34 & High & 47 & High & 13 \\
5 & Student 5 & 42 & High & 44 & High & 2 \\
6 & Student 6 & 46 & High & 55 & High & 9 \\
7 & Student 7 & 40 & High & 44 & High & 4 \\
\hline
\end{tabular}




\section{FINDINGS}

0As mentioned in the background that the guidance used for treatment is group guidance with a Pre-test-Post-test one group design. The comparison of problem items between before and after is listed in table 1 and The results of Pre-test-Post-test is contained in table 2 .

Items that have a low value are at no. 3 which is included in the impulse control indicator, while no. the item that has a high value is no. 9 which is included in the empathy indicator. This means that in general students have problems with controlling the impulses that exist but have high empathy.

The results of the Pre-test showed that there were 5 students in the category of high resilience and 2 students with moderate resilience. After the treatment, a post-test was held. The results show that all students have a high resilience category after treatment. Then, different test was carried out with non-parametric statistics using the Wilcoxon technique.

\begin{tabular}{lllll} 
Ranks & & & & \\
& & $N$ & Mean Rank & Sum of Ranks \\
\hline Postes & Negative Ranks & 0a &, 00 &, 00 \\
Pretes & Positive Ranks & 7b & 4,00 & 28,00 \\
& Ties & 0c & & \\
& Total & 7 & & \\
\cline { 2 - 4 } & & &
\end{tabular}

a. Postes $<$ Pretes

b. Postes $>$ Pretes

c. Postes $=$ Pretes

\begin{tabular}{ll}
\multicolumn{1}{c}{ Test Statistics $^{\mathrm{a}}$} \\
\hline $\mathrm{Z}$ & Postes - Pretes \\
\hline Asymp. Sig. (2-tailed) & $-2,371 \mathrm{~b}$ \\
&, 018 \\
\hline
\end{tabular}

a. Wilcoxon Signed Ranks Test

b. Based on negative ranks.

Based on the results of the Wilcoxon test above, it was found that the value of $\mathrm{Z}=-2.371$ with asymp sid (2-tailed) 0.018 which means that there is a significant difference between the Pre-test and Post-test which can be interpreted that there is a significant difference in student resilience between before and after the guidance was applied. group based on the character of merchants.

\section{Discussion}

The implementation of treatment with group guidance based on the character of budi saudagar according to Prayitno (2004), the steps are the Formation Stage, at this stage the purpose of group guidance based on the character of merchants is conveyed and forming a good relationship by getting acquainted with mentioning favorite names to be called after
There is an interlude activity, namely singing forward songs without being afraid to keep the spirit and make sure the relationship is well formed.

Based on the results of the Wilcoxon test above, it was found that there is a significant difference between the Pretest and Post-test which can be interpreted that there is a significant difference in student resilience between before and after the guidance was applied. As previous research conducted by Supriyanto and Wahyudi (2017) that group guidance using local strengths such as folklore has been proven to be effective in increasing the potential that exists in junior high school students. Supriyanto et al's findings in 2019 were also strengthened that guidance and counseling services based on local wisdom were also able to create peace and were able to facilitate student development.

The subject who experienced significant changes was Student 3, this was because he felt confident because his existence was well received, opinions were valued and increased understanding regarding how to increase resilience. As revealed by Irdanelli and Syahniar (2015) that group guidance is able to increase self-confidence through a series of processes it goes through. Similar to what was revealed by Nurdiyanti, et al in their research that group guidance is able to increase the attitude of respect for others.

The indicators that experienced a lot of improvement were optimism and empathy. These results indicate that group guidance is able to increase both optimism and empathy. As previous research conducted by Mufiqoh, et al (2018), 10 students who had low empathy and social interaction were then given treatment in the form of group guidance with film media. The results of the different test using the Wilcoxon technique showed the value of $Z=-2.803 ; p<0.01$ which indicates that the Post-test empathy value is higher than the empathy value at the Pre-test. The data shows that there is a change of $6.05 \%$ from $64.16 \%$ to $70.21 \%$. This means that group guidance using film media has been proven to be effective in increasing students' empathy and social interaction. Another study conducted by Gunawan et al (2019) also showed the effectiveness of group guidance in increasing the empathy of secondary students.

Research conducted by Mardhatillah, (2017) about effective strategies that can be carried out by Guidance Counseling in improving students of Madrasah Tsanawiyah Diniyah Puteri Pekanbaru can be carried out using Individual Counseling services and Group Guidance services. Research conducted by Agustin (2019), also shows the effectiveness of group guidance services with simulation techniques in increasing optimism in Nurul Jannah Kudus orphanage children.

\section{Conclusion}

Based on the results of the Wilcoxon test with Asymp. Sig. $=0.018$ for the two-sided test, the data results show that the value of $Z=-2.371$ with an alpha of $0.05 \leq 1 \leq 2$, meaning that 
there is a significant difference between Pre-test and Posttest. So the question of research has been answered and this mean that the hypotesis about there are significant difference in student resilience between before and after the application of group guidance based on the character of merchants was accepted. The student who experienced a significant difference in resilience was student no.3. The indicators that experienced many changes were the indicators of empathy and optimism, while those that did not experience much difference were impulse control.

\section{Suggestion}

For Further research can be done by applying group guidance by exploring more characters with more samples. In addition to this type of research, other types of research can be used, for example research and development (R\&D) such as developing a guide to improve student resilience or experimental research with other types such as Pre-test-Post-test one control group design to produce more optimal results.

\section{LIMITATION}

The limitation in this research is the number of subjects studied for group guidance services. Because in essence group guidance can be applied to the number of subjects 8-12 people. Besides that, there are also weaknesses in the research design which only uses the type of Pre-test-Post-test one group design. Besides, the characters contained in the group guidance are only a small part of the characters that exist in Javanese society.

\section{References}

Bastaminia A., M.R. Rezaei and Yosef, T. Resilience and Quality of Life among Students of Yasouj State University. International Journal of Research in Humanities and Social Studies. Volume 3, Issue 8, August 2016, PP 6-11.

Gamble,B and Crouse, D. Strategies for Supporting and Building Student Resilience in Canadian Secondary and Post-Secondary Educational Institutions. Scimedjournal. Vol2 no.2 2020

Farida, A., Bakhtiar Ilham, M. The Development of Group Guidance Service Model to Increase The Competence Of Counselor Candidate. Guidena, 2017 Vol 7 (1).

M. Farquhar, J., K. Kamei, R., R. Vidyarthi, A. Strategies for enhancing medical student resilience: student and faculty member perspectives, January 2018.

Daryanto, J. Pendidikan Karakter Dalam Serat Sana Sunu Karya $R$ Ng. Yasadipura II. Jurnal Pendidikan Dasar Vol. 5 no2 tahun 2017.

Eşkisu, M. (2021). The role of proactive personality in the relationship among parentification, psychological resilience and psychological well- being. International Online Journal of Education and Teaching (IOJET), 8(2). 797-813.
Gunawan, I. M.S., Edi Wibowo.M., Purwanto.E., Sunawan. Group Counseling of Values Clarification to Increase Middle School Students' Empathy Educational Psychology. Vol. 25. Núm. 2. - 2019. Páginas 169 - 174

Hopkins KD, Zubrick SR, Taylor CL Resilience amongst Australian aboriginal youth: an ecological analysis of factors associated with psychosocial functioning in high and low family risk contexts. . PLoS One. 2014 Jul 28;9(7):e102820. doi: 10.1371/journal.

Hopkins KD, Shepherd CC, Taylor CL, Zubrick SR. Relationships between Psychosocial Resilience and Physical Health Status of Western Australian Urban Aboriginal Youth. . PLoS One. 2015 Dec 30;10(12):e0145382. doi: 10.1371/journal.

Hopkins KD, Zubrick SR, Taylor CL. .Psychosocial resilience and vulnerability in Western Australian aboriginal youth. Child Abuse Negl. 2018 Apr;78:85-95. doi: 0.1016/j.chiabu.2017.11.014. Epub 2017 Dec 15.

Irdanelli , Neviyarni, Syahniar. Effectiveness Of Group-Guidance To Increase Student's Self Confident. Syahniaro. Konselor; Vol 4, No.2 tahun 2015

Mardhatillah, (2017) : StrategiGuru Bimbingan Konselingdalam MeningkatkanOptimisme Siswi MadrasahTsanawiyah Diniyah Puteri Pekanbaru

Mufiqoh, A., Sugiharto, DYP \& Tri Anni, C. The Effectiveness of Group Guidance with Film Mediato improve Students' Empathy and Social Interaction. Jurnal Bimbingan Konseling7 (2) (2018):96-100.

Nurdiyanti ,ID and Eddy Wibowo, M .The Effectiveness of Group Guidance Using Film Media and Assignment Technique to Develop Students Respect Attitude. Jurnal Bimbingan dan Konseling. Vol 8 No 4 (2019): October 2019.

Prayitno. 2004. Layanan Bimbingan Kelompok Konseling Kelompok. Padang: Universitas Padang.

Reivich, K. \& Shatte, A. (2002). The Resilience Factor. New York: Broadway Books.

Rosita, L. Peran Pendidikan Berbasis Karakter dalam Pencapaian Tujuan Pembelajaran di Sekolah.Jurnal Ilmu Politik dan Komunikasi Volume VIII No. 1 / Juni 2018

Shatté, A, Perlman, Adam MD., Smith, B. Lynch, Wendy D. The Positive Effect of Resilience on Stress and Business Outcomes in Difficult Work Environments. Journal of Occupational and Environmental Medicine: February 2017 - Volume 59 - Issue 2 - p 135-140.

Supriyanto .A, Amien Wahyudi. Group Guidance Services Based On Folklore For Students Junior High School. 2017. https://ejournal.usd.ac.id/index.php/IJIET/article/view/956

Supriyanto A, Saputra.W, Astuti B. Peace Guidance and Counseling Based on Indonesian Local Wisdom. Atlantis, 2019.

Sumodiningrat, G dan Wulandari, A. 2014. Pitutur Luhur Budaya Jawa. Yogyakarta : Narasi.

Wexler L, Joule L, Garoutte J, Mazziotti J, Hopper K. "Being responsible, respectful, trying to keep the tradition alive:" cultural resilience and growing up in an Alaska Native community. Transcult Psychiatry. 2014 Oct;51(5):693-712. doi: 10.1177/1363461513495085. Epub 2013 Sep 6. PMID: 24014513 